\title{
Global Relapse in Skin
}

National Cancer Institute

\section{Source}

National Cancer Institute. Global Relapse in Skin. NCI Thesaurus. Code C159956.

Any disease recurrence in those with complete response. 